\title{
SESSIONAL CONTRACT FACULTY, UNIONIZATION, AND ACADEMIC FREEDOM
}

\author{
STEPHANEROSS \\ MCMASTER UNIVERSITY
}

\author{
LARRY SAVAGE \\ BROCK UNIVERSITY
}

\author{
JAMES WATSON \\ MCMASTER UNIVERSITY
}

\begin{abstract}
This article explores the relationship between unionization and academic freedom protections for sessional faculty in Ontario universities. Specifically, we compare university policies and contract provisions with a view to determining whether unionized sessionals hired on a per-course basis have stronger academic freedom protections than their non-union counterparts. We then explore whether particular kinds of bargaining unit structures are more conducive to achieving stronger academic freedom provisions. Finally, we consider whether academic freedom can be exercised effectively by sessionals, whether unionized or not. We conclude that unionization does help to produce stronger academic freedom protections for sessional faculty and that faculty association bargaining unit structures are most likely to help deliver this outcome. We further conclude that academic freedom is difficult to exercise for sessional faculty, regardless of union status, but that unionization offers greater protections for sessionals facing repercussions as a result of asserting their academic freedom.

Keywords: academic freedom, sessional instructors, contract faculty, faculty associations, unions, bargaining unit structures
\end{abstract}

\section{Résumé}

Cet article explore la relation entre la syndicalisation et la protection de la liberté académique pour les chargés de cours des universités de l'Ontario. Plus précisément, nous comparons les politiques universitaires et les dispositions contractuelles afin de déterminer si les chargés de cours syndiqués bénéficient d'une meilleure protection de leur liberté académique que leurs homologues non syndiqués. Nous examinons ensuite si certaines structures d'unités de négociation sont plus propices à la mise en place de dispositions favorisant la liberté académique. Finalement, nous examinons si la liberté académique peut être exercée efficacement par les chargés de cours, syndiqués ou non. Nous concluons que la syndicalisation aide à la création de mesures de protection de la liberté académique pour les chargés de cours et que les associations de professeurs, comme structures d'unités de négociation, sont les plus susceptibles de contribuer à atteindre ce résultat. En outre, nous concluons que la liberté académique est difficile à exercer pour les chargés de cours, quel que soit leur statut syndical, mais que la syndicalisation leur offre une plus grande protection lorsqu'ils subissent des répercussions en raison de l'affirmation de leur liberté académique.

Mots-clés : liberté académique, chargés de cours, enseignants contractuels, associations de professeurs d'université, syndicats, structures d'unités de négociation

\section{Introduction}

It is widely acknowledged that academic freedom is essential to the educational mission of universities. Peter Mackinnon (2018), a former university president and chair of the Association of Universities and Colleges of Canada (now Universities Canada), argues that "all peo- ple within universities, or who understand them, appreciate that academic freedom is a necessary condition for their activities" (p. 65).

MacKinnon concedes, however, that both the meaning and scope of academic freedom are highly contested in Canadian higher education. He offers a two-part definition of academic freedom: "the freedom to teach 
and conduct research constrained only by (1) the professional standards of the relevant discipline, and (2) legitimate and non-discriminatory institutional requirements for organizing the academic mission" (MacKinnon, 2014, p. 62).

James Turk (2014), a former executive director of the Canadian Association of University Teachers (CAUT) and director of Ryerson University's Centre for Free Expression, offers a broader interpretation of academic freedom's scope and meaning. He describes academic freedom as a

right to freedom from prescribed orthodoxy in their teaching, research, and lives as academics; a right necessary so that teaching and scholarly research are not corrupted by the will of politicians, special interest groups, religious authorities, the media, corporations, donors, or board members. (p. 11)

He goes on to argue that academic freedom is not a privilege, "but the foundation that makes possible the work of academics to fulfill their societal obligation to advance knowledge and educate students" (p. 11). Turk (2017) argues that academic freedom has four core elements:

The first two are the freedom to teach and the freedom to conduct research based on each academic's best professional judgment, not beholden to prevailing orthodoxy or outside interests. The third element is "extramural" academic freedom-the ability of academics to exercise their rights as citizens without sanction by the university administration or board of governors. The final element is "intramural" academic freedom - the right to comment publicly on any aspect of the university, which is necessary if the university's academic life is to be collegially self-governed. (p. 7)

The difference between the definitions offered by MacKinnon and Turk, respectively, is primarily about the scope of academic freedom. Horn (1999) explains that the "narrow definition of academic freedom limits it to the freedom of professors to teach their subjects, carry out research, and publish its results, subject to professionally sanctioned limits," while the broader interpretation, favoured by CAUT, emerged in earnest in the 1960s (p. $x)$. That wider notion of academic freedom included "the freedom to participate in public life and, perhaps still controversially, to criticize the institutions in which professors work" (p. x).
Since the 1960s, this broader interpretation of academic freedom has gradually, albeit unevenly, gained acceptance. In 1997, the United Nations Educational, Scientific and Cultural Organization (UNESCO) adopted a series of recommendations concerning the status of higher education teaching personnel in relation to both labour rights and academic freedom. The recommendations were heavily influenced by CAUT (Savage \& Finn, 2017). Notably, the UNESCO recommendations established as an international norm that "tenure or its functional equivalent...constitutes one of the major procedural safeguards of academic freedom and against arbitrary decisions" (Savage \& Finn, 2017, p. 15). The UNESCO statement, however, is non-binding, and university administrations in Canada have been loathe to embrace its recommendations, in particular in relation to job security and academic freedom.

In 2011, Universities Canada attempted to narrow the scope and definition of academic freedom by excluding reference to intramural and extramural academic freedom in its revised policy statement (Turk, 2017). Attempts to establish more narrow parameters for academic freedom are driven by risk aversion on the part of senior administrators and university boards, fearful that a member of academic staff will irreparably damage a university's reputation by publicly criticizing the institution or by going outside of their field of expertise and taking a very unpopular stand on a controversial matter of public policy. The irony, of course, is that universities increasingly emphasize the importance of developing stronger university-community linkages in order to break down barriers between town and gown. ${ }^{1}$ Dea (2018) puts it best: "I often observe that we want our Einsteins to be able to go beyond physics and discuss world peace in public, if they wish to do so. If engaging with the public is indeed part of the job of the professor, the argument goes, then universities ought to protect professors who take up the task."

Academic freedom, however, is not only being undermined from within. Its boundaries are also being targeted by external forces from across the political spectrum. The corporatization of universities raises real concerns about faculty's ability to conduct research without the influence or interference of corporate donors (Brownlee, 2015; Polster, 2015; Woodhouse, 2009). The rise of so-called "cancel culture" and "woke" liberalism, we are told, threatens to limit the boundaries of scholarly debate in ways that undermine the independent pursuit 
of knowledge (David, 2020). Codes of conduct mandating civility and respect threaten to marginalize or silence voices of dissent within the university (Cameron, 2014). Universities' loss of institutional autonomy from governments undermines the ability of faculty members to propose, and for universities to mount, courses and academic programs that do not align with government-enforced mandates (Neem, 2019). Finally, the erosion of tenure and shared governance in universities arguably renders academic freedom meaningless for the growing ranks of sessional instructors who cannot meaningfully exercise academic freedom without the promise of job security (Frontczak, 2020; Hanke, 2017). In the words of Hussein and MacDermid (2006),

The limited term employment of teachers and researchers is not conducive to claims of academic freedom. Those who wish to have employment continued are not likely to make statements that challenge conventional understandings or challenge the goals and directions of the university. (p. 11)

This latter threat to academic freedom is the major focus of this research.

Because the university sector is among the most densely unionized in Canada, unionization and collective agreements play a key role in the promotion and defence of academic freedom. Thus, while scholarly exchange and policy statements concerning the scope of academic freedom can help us put these various debates into context, in a practical sense, the parameters of such debates are typically constrained by specific collective agreement provisions, where such union contracts exist, and the interpretation of those provisions.

After a review of the history and development of academic freedom in Canada, this article explores the relationship between unionization and academic freedom protections for sessional faculty in Ontario universities. We chose the province of Ontario as the focus for our study on contract sessional faculty and academic freedom because it is home to the largest number of universities and university personnel in Canada, has a good cross-section of differentiated bargaining unit structures, and has one of the highest proportions of contract academic staff in Canada. First, we compare relevant university policies and collective agreement provisions related to academic freedom with a view to determining whether or not unionization provides sessionals with stronger academic freedom provisions. Second, we consider whether particular kinds of bargaining unit structures are more conducive to stronger academic freedom provisions. And finally, we consider whether or not academic freedom can be exercised effectively by precariously employed sessionals, regardless of bargaining unit or union status.

\section{History and Context}

Academic freedom, in a codified form, first emerged in early nineteenth-century Germany as part of the Humboldtian model of higher education, which holistically combined teaching and research (Dea, 2018). The concept of academic freedom was considered key to ensuring that the pursuit of knowledge would remain independent from political or religious pressures. In the early twentieth century, key features of the Humboldtian model, including the idea of the research-based university rooted in academic freedom, gained favour among professors in the United States. In 1915, amid a maelstrom of academic freedom controversies, the American Association of University Professors (AAUP) endorsed a statement of principles on academic freedom and tenure focused on three elements of academic freedom for professors: "freedom of inquiry and research; freedom of teaching within the university or college; and freedom of extra-mural utterance and action" (AAUP, 1915, p. 1). The influential statement was later modified and in collaboration with the Association of American Colleges to produce the "1940 Statement of Principles on Academic Freedom and Tenure," which contained some important caveats, including that "limitations of academic freedom because of religious or other aims of the institution should be clearly stated in writing at the time of the appointment" and that, in the exercise of extramural academic freedom, faculty "should make every effort to indicate that they are not speaking for the institution" (AAUP, 1940, paras. 10, 11).

In the Canadian context, Horn (1999) argues that academic freedom has never been a "burning issue" in the same way that it has south of the border (pp. 3-14). He explains that

by the outbreak of the 1914-18 war, teaching and research were generally protected, but free speech outside the classroom remained insecure, and public criticism of one's institution, its head, or its governing board was very likely to lead to dismissal. (p. 350) 
Tudiver (1999) argues that faculty "could be dismissed for stating unpopular opinions or criticizing their employers" (p. 34). This was especially true in times of war or economic instability. Indeed, the Great Depression and Cold War both reinforced calls to restrict academic freedom, which was seen as a tool to share radical political ideas (Horn, 1999, p. 350). Tudiver (1999) contends that "when academics spoke out against political or economic injustice, or voiced unpopular opinions, they risked direct repercussions from employers" and "openly disagreeing with university policies, especially within sectarian institutions, could land them in serious trouble" (p. 35). The landmark 1958-1959 Crowe case, however, proved pivotal to the expansion and embrace of academic freedom protections for Canadian professors and precipitated CAUT's formal adoption of a policy statement on academic freedom and tenure, 45 years after the AAUP's 1915 "Statement of Principles on Academic Freedom and Tenure."

Professor Harry S. Crowe was a permanent faculty member at United College (now University of Winnipeg) whose termination in 1958 sparked a heated national debate about academic freedom and tenure in Canadian universities. After obtaining an intercepted copy of a private communication between Crowe and a colleague, in which Crowe expressed fears of a Conservative landslide in the upcoming federal election and described religion as a "corrosive force," the College's principal alerted the College's Board of Regents (Horn, 1999, pp. 223-233). Crowe was subsequently fired without ever being asked by the board to address, let alone defend, the contents of the private letter. Several of his colleagues resigned in protest and CAUT established an ad hoc committee of inquiry to investigate.

In 1959, the landmark Fowke-Laskin Report, commissioned by CAUT, concluded that Crowe's firing was "an unjust and unwarranted invasion of the security of academic tenure" (CAUT, 1959, p. 46). On the subject of academic freedom, specifically, the report emphasized that

academic freedom would be vulnerable if its limits depended on the interpretation placed by a college administrator on the remarks of a member of the academic staff.... Indeed, it is no part of the function of a professor to speak only in accents familiar to the administration.
The report concluded:

To find a discharge made in the face of a remonstrance by the teacher that he has been misunderstood, and without being afforded an opportunity of explanation, makes the offence against academic freedom grave indeed. This is what happened in the instant case." (CAUT, 1959, p. 39)

The report went on to argue that "academic freedom and tenure are not mutually exclusive either as ideas or as realities and they cannot be analysed in separation" (CAUT, 1959, p. 40). Furthermore, the report asserted that

academic freedom and security of tenure are neither ends in themselves nor the exactions of special privilege but merely conditions indispensable for the performance of the purposes of higher education; that the search for truth which is the central purpose of institutions of higher learning cannot prosper without freedom of inquiry and expression; and finally, that security of tenure is prerequisite to academic freedom. (CAUT, 1959, p. 40)

The Fowke-Laskin Report not only built support for broader interpretations of academic freedom among university professors, but also fast-tracked CAUT's process of adopting its own statement on academic freedom and tenure along with procedures to investigate violations (Horn, 1975, p. 15).

CAUT's statement on academic freedom and tenure, ratified in 1960, was more or less modelled after the AAUP statement, but in an abridged form and with seemingly fewer self-imposed limits. For example, in assessing the content of the statement, Savage and Holmes (1975) argue that CAUT's "Executive and Council rejected the then AAUP view that there could be justifiable limitations on academic freedom notably in religious institutions, and that an academic had to dissociate himself from his institution when making public statements" (p. 26). Horn (1999) argues that the Crowe case and the FowkeLaskin Report that followed strengthened support for the concept of intramural academic freedom among faculty, asserting "henceforth professors were likely to appeal to the principle of academic freedom when they criticized administrators or governing boards" (pp. 26-27).

The Fowke-Laskin Report also prompted many universities to sign agreements that required boards to 
demonstrate just cause if they sought to fire a tenured faculty member (Horn, 1999, p. 351). As Tudiver (1999) notes, it was a desire to strengthen and protect tenure and academic freedom as "fundamental aspects of their work" that "eventually drove faculty toward unionization" in the early 1970s (p. 34).

While the impetus behind union certification was campus-specific and changed over time, the growth of unionization in the university sector would play an important role in securing legally enforceable academic freedom protections for faculty. But as tenured and tenure-stream faculty increasingly opted to unionize in waves throughout the 1970s, 1980s, and 1990s, the share of non-permanent contract academic faculty began to grow at an increasingly significant rate (Rajagopal, 2002). While a small number of faculty associations certified as unions that included both tenured and sessional faculty, most did not. This forced many sessional contract faculty to pursue unionization on their own, and many did as part of the Canadian Union of Educational Workers, which was absorbed by the Canadian Union of Public Employees in the 1990s (Axelrod, 1982, p. 204; Ross et al., 2020). By the late 1990s, full-time faculty in Canada were unionized at all but a dozen universities, while their comparatively lower-paid precarious contract-based sessional counterparts remained unorganized on many university campuses. By the turn of the 21st century, CAUT had identified the growth of sessional contract academic faculty as an impending threat to tenure, academic freedom, and an assortment of monetary terms and conditions of work traditionally associated with the university teaching profession. CAUT leaders saw the unionization of per-course instructors as the key to rendering their labour more expensive and thus mitigating their growth within the sector. These arguments were used to convince some of the remaining non-union faculty associations to certify using an all-in bargaining unit model that would, in theory, lessen a university administration's ability to pit tenured faculty against sessionals (Ross et al., 2020).

A significant literature exists on the precarious nature of sessional contract academic faculty and the negative effects the proliferation of sessional appointments poses to academic freedom and the collegial governance of universities in Canada (Banks, 1995; Birdsell Bauer, 2017; Brownlee, 2015; Hanke, 2017; Hughes \& Bell, 2015; Rajagopal, 2002; Smallman, 2006; Turk, 2017).
Turk (2017) argues that while academic freedom was "originally developed to protect academic work from inappropriate interference by external forces," it is increasingly "being undermined internally within the university" (p. 6). This silent erosion of academic freedom is particularly concerning for the growing ranks of sessional contract faculty in Canadian universities since they are far more vulnerable than their permanent counterparts to non-renewal or termination.

In their 2015 study, which reviewed collective agreement provisions for unionized contract faculty at 19 universities across English Canada, Hughes and Bell identify 16 that include academic freedom provisions. However, they also find that while "many collective agreements included a reference to academic freedom, only 31 percent gave employees the express freedom to criticize their employer and did not limit academic freedom to their discipline" (Hughes \& Bell, 2015, p. 390). Moreover, their data indicated that "faculty associations negotiated four of the six collective agreements that protected academic freedom fully" (p. 390). We use this study as a reference point to further investigate the relationship between academic freedom provisions, union status, and bargaining unit status for sessional contract faculty in Ontario universities.

\section{Methodology}

Our quantitative analysis is based on a review of collective agreement provisions and university policies concerning academic freedom for sessionals across 27 Ontario universities. To determine whether there were quantifiable patterns based on union status and bargaining unit structure, we developed an Academic Freedom Provision Index (AFPI) to measure and rank the relative strength of academic freedom provisions at each university Each university was given a score from $0-4$. This was accomplished by coding policy or contract language based on a standardized set of measurements and scoring criteria. The evaluation criteria for the AFPI was based on the following four dimensions of academic freedom: (a) Freedom to teach, (b) freedom to research, (c) extramural freedom, and (d) intramural freedom. Scoring was conducted by awarding a single point (1.0) for each dimension explicitly covered by contract or policy provisions, followed by half-point $(0.5)$ deductions for any significantly limiting caveats related to each dimen- 
sion that were outside the norm for the sector.

Freedom to teach was broadly assessed based on the robustness of provisions that protect sessionals' ability to determine pedagogical methods, course content, and design. Freedom to research was assessed based on the existence of provisions that guaranteed the right to choose research topics, publish research, and discuss research results without limitation, fear of reprisal, or institutional censorship. Provisions for extramural freedoms were assessed based on several factors, including language that permits sessionals to exercise their rights as citizens without sanction by administrators, and intramural freedom was measured based on the existence of explicit provisions that secure a right to comment, without censorship or reprisal, on any aspect of the university.

For each of these dimensions, the strength of the provision and the subsequent score was based on the robustness and expansiveness of the explicit language contained in the policy or collective agreement. Relatedly, caveats designed to significantly limit the exercise of academic freedom were used as grounds for a scoring deduction. For example, provisions for teaching freedom that included language reserving the right of department chairs or administrators to determine certain course content or assign particular textbooks were subject to deductions. Provisions that mandated intramural freedom be exercised within undefined boundaries of reasonableness were also grounds for a scoring deduction.

The entire collective agreement, rather than the specific provisions related to academic freedom, was taken into consideration because protections understood as affording explicit protections are sometimes embedded in general contract terms rather than clauses specific to academic freedom. Thus, anyone conducting a word search of a collective agreement may not find the specific reference to a provision in the text even though the general language is rightly taken to afford the protections that do exist in law and practice.

In cases where universities had academic freedom policies embedded in both policies and collective agreements, we used the collective agreement provisions for the purposes of assessment because in each case the agreements superseded the university's general policy statements. The University of Waterloo and Renison University College are the only campuses in Ontario where sessional faculty are not unionized, and policy documents rather than collective agreements were used to assess criteria in those cases.

We also sorted unionized cases by bargaining unit status (see Table 1). The three variations at play were: (a) sessional contract academic faculty and full-time academic faculty at the same university grouped together in the same union and same bargaining unit for the purposes of collective bargaining (the all-in model); (b) sessional contract academic faculty and full-time faculty teaching at the same university represented by the same union, but are in separate bargaining units for the purposes of collective bargaining; and (c) full-time faculty and sessional contract faculty working at the same university represented by separate unions or associations.

\section{Research Findings}

While it is important to acknowledge that bargaining structures, on their own, cannot explain why some contract provisions are better than others, the data reveal a clear pattern that suggests a strong relationship exists between union status, bargaining unit status, and the strength of academic freedom protections.

In Table 2 we aggregated individual AFPI scores by union status and bargaining union structure. Separate bargaining unit faculty associations had the strongest provisions for academic freedom, with an average score of 3.88. All four cases had collective agreements that contained provisions for teaching, research, extramural, and intramural academic freedoms. All-in faculty associations were close behind with an average score of 3.17 based on nine cases. A much larger gap existed between sessionals represented by unionized faculty associations and sessionals represented by separate public sector unions. The latter group had an average score of 2.29 based on 12 cases, while non-unionized sessionals scored 1.0 based on just two cases. 
Table 1

Academic Freedom Provision Index - Cases

\begin{tabular}{|c|c|c|}
\hline Bargaining Unit Structure & University or College & Bargaining Union/Unit \\
\hline All-in Faculty Associations & $\begin{array}{l}\text { Brescia } \\
\text { Huron } \\
\text { Lakehead } \\
\text { Laurentian } \\
\text { NOSM } \\
\text { OCADU } \\
\text { Queen's } \\
\text { Western } \\
\text { Windsor }\end{array}$ & $\begin{array}{l}\text { BFA } \\
\text { HUCFA } \\
\text { LUFA } \\
\text { LUFAPPUL } \\
\text { NOSM-FSA } \\
\text { OCADFA } \\
\text { QUFA } \\
\text { UWOFA } \\
\text { WUFA }\end{array}$ \\
\hline $\begin{array}{l}\text { Separate Bargaining Unit Faculty } \\
\text { Associations }\end{array}$ & $\begin{array}{l}\text { Algoma } \\
\text { Nipissing } \\
\text { St. Jeromes } \\
\text { Wilfrid Laurier }\end{array}$ & $\begin{array}{l}\text { AUFA-CAS } \\
\text { NUFA-CASBU } \\
\text { SJU-CAS } \\
\text { WLUFA-CAS }\end{array}$ \\
\hline Separate Unions & $\begin{array}{l}\text { Brock } \\
\text { Carleton } \\
\text { Guelph } \\
\text { Kings } \\
\text { McMaster } \\
\text { Ottawa } \\
\text { Ryerson } \\
\text { Saint Paul } \\
\text { Toronto } \\
\text { Trent } \\
\text { UOIT } \\
\text { York }\end{array}$ & $\begin{array}{l}\text { CUPE } 4207 \\
\text { CUPE } 4600 \\
\text { CUPE } 3913 \\
\text { CUPE } 5265 \\
\text { CUPE } 3906 \\
\text { APTPUO } \\
\text { CUPE } 3904 \\
\text { PSAC-Saint Paul } \\
\text { CUPE } 3902 \\
\text { CUPE } 3908 \\
\text { PSAC-UOIT } \\
\text { CUPE } 3903\end{array}$ \\
\hline Non-Unionized & $\begin{array}{l}\text { Waterloo } \\
\text { Renison }\end{array}$ & \\
\hline
\end{tabular}

\section{Table 2}

Academic Freedom Provision Index - Aggregate by Bargaining Unit Structure

\begin{tabular}{lll}
\hline Bargaining Unit Structures & Average & \# of cases \\
\hline All-in faculty associations & 3.17 & 9 \\
Separate bargaining unit faculty associations & 3.88 & 4 \\
Separate unions & 2.29 & 12 \\
Non-unionized & 0.50 & 2 \\
\hline
\end{tabular}


Table 3

Academic Freedom Provision Index - Inclusions and Exclusions by Bargaining Unit Structure

\begin{tabular}{|c|c|c|c|c|}
\hline Bargaining Unit Structure & $\begin{array}{l}\text { University or } \\
\text { College }\end{array}$ & $\begin{array}{c}\text { Bargaining Union/ } \\
\text { Unit }\end{array}$ & $\begin{array}{c}\text { AFPI } \\
\text { Provision }\end{array}$ & $\begin{array}{l}\text { Total } \\
\text { Score }\end{array}$ \\
\hline \multirow[t]{9}{*}{ All-In Faculty Associations } & Huron & HUCFA & TREI & 4 \\
\hline & Lakehead & LUFA & TREI & 4 \\
\hline & Laurentian & LUFAPPUL & TREI & 4 \\
\hline & Western & UWOFA & TREI & 4 \\
\hline & Brescia & BFA & TREI & 3.5 \\
\hline & Windsor & WUFA & TREI & 3.5 \\
\hline & NOSM & NOSM-FSA & TRI & 3 \\
\hline & Queen's & QUFA & TRI & 3 \\
\hline & OCADU & OCADFA & TR & 1.5 \\
\hline Separate Bargaining Unit & Nipissing & NUFA-CASBU & TREI & 4 \\
\hline \multirow[t]{3}{*}{ Faculty Associations } & St. Jerome's & SJU-CAS & TREI & 4 \\
\hline & Wilfrid Laurier & WLUFA-CAS & TREI & 4 \\
\hline & Algoma & AUFA-CAS & TREI & 3.5 \\
\hline \multirow[t]{12}{*}{ Separate Unions } & Trent & CUPE 3908 & TREI & 4 \\
\hline & Kings & CUPE 5265 & TREI & 3.5 \\
\hline & Ryerson & CUPE 3904 & TRI & 3 \\
\hline & Saint Paul & PSAC-Saint Paul & TRI & 3 \\
\hline & UOIT & PSAC-UOIT & TRI & 3 \\
\hline & Ottawa & APTPUO & TRI & 2.5 \\
\hline & Brock & CUPE 4207 & $\mathrm{TI}$ & 2 \\
\hline & Toronto & CUPE 3902 & $\mathrm{TI}$ & 2 \\
\hline & York & CUPE 3903 & $\mathrm{TI}$ & 2 \\
\hline & Carleton & CUPE 4600 & TR & 1.5 \\
\hline & Guelph & CUPE 3913 & $\mathrm{TI}$ & 1 \\
\hline & McMaster & CUPE 3906 & $\mathrm{~N} / \mathrm{A}$ & 0 \\
\hline \multirow[t]{2}{*}{ Non-Unionized } & Waterloo & & TR & 2 \\
\hline & Renison & & $\mathrm{N} / \mathrm{A}$ & 0 \\
\hline
\end{tabular}

Note: $\mathrm{T}$ = Teaching; $\mathrm{R}$ = Research; $\mathrm{E}=$ Extramural; $\mathrm{I}$ = Intramural

The data in Tables 2 and 3 point to two important findings. First, unionized sessionals have much stronger academic freedom provisions than their non-union counterparts, and second, unionized sessionals who belong to faculty associations have more robust academic freedom protections than their counterparts represented by other kinds of public sector unions. Why is this the case?

Non-unionized sessional faculty at Waterloo and Renison College had among the lowest AFPI scores (see Table 3). In the case of Waterloo, while university policy provides for teaching and research freedoms for sessionals, neither of these provisions are legally enforceable and are subject to change based on managerial and administrative prerogatives. Tellingly, academic freedom policies for sessionals at Waterloo and Renison respectively are embedded within broader policy documents concerning "Ethical Behaviour" in the case of Waterloo, and "Discrimination and Harassment" in the case 
of Renison. By their very design, these policy documents approach academic freedom as something to be limited or constrained by the wider policy objectives aimed at fostering sensitivity, respect, and tolerance. Moreover, the policies contain no remedies for violations of academic freedom and complaint processes seem only to contemplate cases of harassment, discrimination, or accusations of unethical behaviour. In short, the limited academic freedom provisions for sessionals at these universities lack genuine force or effectiveness.

In the case of unionized sessionals, it is important to underscore that, unlike their non-union counterparts, they have access to grievance procedures and legally binding arbitration as mechanisms to protect and defend their exercise of academic freedom, thus rendering the academic freedom provisions in their contract more robust.

Unionized sessionals represented by faculty associations scored highest on the AFPI. A strong majority (10 out of 13) of unionized faculty associations had explicit provisions for teaching, research, extramural, and intramural freedoms (see Table 3). In their own national study, which yielded similar findings, Hughes and Bell (2015) argued "this suggests that CAUT affiliates may be putting a higher premium on protecting academic freedom than public service unions" (p. 390). This is a reasonable explanation, but one that could use some elaboration. Unionized sessionals who are represented by faculty associations appear to benefit from an academic freedom spillover effect. Academic freedom, especially its provisions related to research and extramural/ intramural freedoms, is often thought of as being most closely associated with the tenure or tenure-track faculty positions that make up the majority of faculty associations' membership. While faculty association collective agreements do sometimes contain language that differentiates between academic freedom rights for sessional and permanent faculty, this is the exception rather than the rule. In general, the status and importance accorded to academic freedom for tenured and tenure-track faculty benefits their sessional counterparts in the same union.

For sessionals represented by other kinds of public sector unions, only two out of 12 collective agreements contained explicit provisions that covered all four dimensions of academic freedom. The provisions most often absent were those for extramural freedoms and research-based freedoms. This latter exclusion is likely explained by the fact that most sessionals do not have a research-based work component and administrators are therefore better positioned to resist efforts to extend academic freedom protections to research endeavours viewed as outside the scope of sessionals' employment. Of the 12 cases, five cases did not have explicit academic freedom provisions related to research. In one case (King's University College), limitations to intramural freedom included a responsibility to promote "the efficient functioning of the College," and to "promote or at least respect the Catholic identity of the College" (Article 13.01 of the collective agreement between King's University College and CUPE Local 5265).

\section{Analysis}

While the data clearly demonstrates that unionized sessionals generally have better academic freedom provisions than their non-union counterparts and that unionized sessionals in faculty associations tend to have better academic provisions than their unionized counterparts in other public sector unions, these findings really only tell half the story.

What is not immediately clear from our review of academic freedom provisions is that the actual exercise of academic freedom for sessionals (both union and non-union) is undermined by their non-permanent status (Hughes \& Bell, 2015; Turk, 2017). While most unionized sessionals, especially those in all-in bargaining units, undoubtedly have greater academic freedom protections than their non-union counterparts, a lack of job security and the structural power imbalances between contract faculty and tenured faculty, let alone deans and other senior administrators, mean that sessionals, in general, are less willing to push the limits of academic freedom for fear of not having their contracts renewed.

In other words, while academic freedom is a long-established and core feature of Canadian universities, and is protected in most collective agreements, for many sessional contract faculty academic freedom operates more like an abstract concept that only meaningfully applies to their tenured counterparts. That is why, in conjunction with demands for strong academic freedom protections, unions representing sessionals have also sought better job security language through the negotiation of seniority provisions, the right of first refusal, strong grievance procedures, and continuing appointments.

These associated rights and protections are criti- 
cally important because complaints from students and colleagues about the teaching, research, and the conduct of sessional faculty can have potentially devastating consequences for career progression. In the U.S. context, Sachs (2018) demonstrates that sessionals are especially subject to termination over the exercise of free speech. In the Ontario context, Field and Jones (2016) usefully remind us that "student feedback and evaluations are not used solely for improving teaching materials, they are also often considered in determining contract renewal and other hiring prospects" (p. 40). While Field and Jones are cautious about drawing solid conclusions, their comprehensive survey of contract faculty suggested that $42 \%$ of precariously employed sessionals may adjust course content as a result of being wary of "the impact of negative student feedback" ( $p$. 40). One interpretation of the data is that, because of the precarious nature of their work, sessionals must be very careful to exercise their academic freedom in a way that does not alienate students or yield negative feedback on student opinion surveys.

While these sources of vulnerability affect all academics, they do so on a continuum, with sessionals undoubtedly situated at its most vulnerable end. The impacts of negative student opinion surveys on tenured and tenure-stream faculty, for example, have been mitigated by arbitration decisions that prevent the use of anonymous student criticism as a basis to deny professors tenure or promotion (Farr, 2018; Horn, 1999, p. 323) While, in theory, these arbitration decisions could be used as a basis to extend similar protections to sessionals, Turk (2017) reminds us "it is very difficult, in practice, to protect the academic freedom of those with little or no job security.... No mention need be made of the real reason, unlike when a regular faculty member is disciplined or dismissed" (p. 7).

It should also be noted that while university administration ultimately makes decisions about hiring and firing sessionals, tenured faculty serving as department heads are typically in the position of making recommendations to that effect. In other words, sessionals are vulnerable on at least three fronts, having to worry about offending not only the administration, but also their students and tenured colleagues. In these circumstances, being perceived as a troublemaker, fiercely independent, or overly assertive is to be avoided at all costs.

While formal grievances may be pursued on behalf of sessionals who argue they were not renewed or re-appointed as a result of their exercise of academic freedom, conclusive proof is hard to come by and may be complicated by the fact that in many cases the union's membership is comprised of faculty members who played a role in recommending non-renewal.

Muzzin (2009) generally concludes that "academic freedom is largely non-existent for contingent faculty at Canadian universities." This is not because academic freedom protections do not exist on paper, but rather because contract faculty's relative lack of power makes them enormously difficult to exercise. Hanke (2017) similarly argues that "without the protection of tenure, contract faculty may limit their expression of political views" and asserts that "only continuous employment can fully protect the full scope of academic freedom, as a pillar of the university" (p. 63).

In reference to pre-tenure faculty, but certainly applicable to a wide range of sessional instructors, Acker and Webber (2016) argue these workers are socialized to make teaching, research, and service decisions that will best suit career advancement. They contend that faculty are expected to participate in "an emotional exercise in making choices that do not stray too far from the norm and produce accountable evidence of achievement.... Individuals put up with the stressful experience because they want a chance at an academic life" (p. 249). As one sessional interviewee quoted in Rajagopal (2002) put it,

We, as part-time people, are very much at the mercy of administration. We have little control over staffing, no involvement with full time faculty and no opportunity to access faculty-level professional development. As a graduate student and as a faculty member I felt the impact of an extremely "political" workplace and a total absence of academic freedom. (p. 125)

In short, sessional instructors have to carefully navigate their choices concerning teaching and research in order to improve their chances at job security and advancement.

In many cases, sessionals must also contend with a proliferation of university policies mandating respect and civility in the workplace that can also have a chilling effect on academic freedom (Cameron, 2014). To illustrate the point, consider the case of Professor Ken Luckhardt, a contract faculty member at King's University College. Turk (2017) explains that Luckhardt was 
permanently banned from campus for writing to the principal advising him not to appoint two colleagues to replace the director of his program who had resigned in protest over university efforts to change the program. Luckhardt's criticism of colleagues was deemed vexatious and objectionable-a claim a subsequent Canadian Association of University Teachers (CAUT) investigation found to be without merit. (p. 7)

CAUT's investigatory report concluded that "Professor Luckhardt's academic freedom was violated. His legitimate criticisms of the academic decisions of the Administration were dispensed with through the application of a harassment proceeding" (Katz \& Haxell, 2013, p. 2). Relevant for the purposes of this research, the then non-certified faculty association at King's University College filed a grievance in response to the decision to permanently ban Luckhardt from campus. However, the faculty member who initiated the harassment complaint against Luckhardt successfully convinced the association to withdraw the grievance.

CAUT's investigatory report raised serious concerns about this dynamic, noting:

Sessional faculty have little power in the academy or protection from administrative abuse in comparison with full-time tenure stream, and especially tenured, faculty. Contract faculty depend on their colleagues and the Administration for their work, often on an individual course-wise basis and as such are reluctant to express critical observations about programs or administrative decisions. We have concerns that the outcome of this case, a ban on Professor Luckhardt from entering campus, may make contract faculty at King's more hesitant to express their opinions and make their expertise available. (Katz \& Haxell, 2013, p. 15-16)

The King's University College Faculty Association strongly condemned the report's findings, arguing that Luckhardt's letter to the principal was sexist, defamatory, and designed to undermine the standing of two female colleagues. Moreover, the faculty association's women's caucus issued its own report, arguing that anti-harassment policies reinforce rather than undermine academic freedom (Ibbott et al., 2014). Despite this rebuke, CAUT threatened censure against the university for its handling of the case and, in response, the principal lifted the ban against Luckhardt in exchange for a commitment from the former sessional to "cease making any more denigrating comments concerning, or directed towards, the complainant" (Sylvester, 2014).

While the lack of arbitration decisions on academic freedom cases involving sessional instructors in Canada makes it difficult to determine whether or not the dynamics of this case are generalizable, the case does effectively highlight the potential severity of vulnerabilities faced by sessionals in the exercise of academic freedom.

\section{Conclusion}

Academic freedom can often be intertwined with competing rights and freedoms that render its exercise messy and complex. However, there is little doubt that the casual nature of sessional contract faculty positions works to undermine academic freedom in higher education. In the case of Ontario, it is clear that unionization has played an important role in bolstering academic freedom protections by providing stronger and legally enforceable contract language as well as due process for those sessionals whose freedoms are violated. Our analysis of the data reveals that, on average, unionized sessionals who are part of faculty association bargaining units have stronger academic freedom contract provisions than their unionized counterparts in separate unions. Moreover, the data reveals that unionized sessionals, regardless of bargaining unit structure, have much stronger academic freedom contract protections than their non-union counterparts who are subject to non-legally binding university policies that may be altered unilaterally at any time by boards or senior administrators.

However, rights on paper do not always translate into rights in practice. While further research is needed to assess the effectiveness of various academic freedom provisions, the major takeaway from our analysis is that while union status and bargaining unit structure have an impact on the strength and scope of academic freedom provisions, it is incredibly difficult for sessionals, in general, to meaningfully exercise their right to academic freedom without fear of reprisal. This is especially true given the power imbalances and vulnerabilities sessionals are most prone to experience. In a way, the assertion made in the Fowke-Laskin Report, "that security of tenure is prerequisite to academic freedom" (CAUT, 1959, 
p. 40), is no less true today than it was in 1959 . This underscores the need for greater sessional job security provisions to give real meaning to academic freedom protections.

\section{Acknowledgements}

This article draws on research supported by the Social Sciences and Humanities Research Council and the Council for Research in the Social Sciences at Brock University.

\section{References}

Axelrod, P. (1982). Scholars and dollars: Politics, economics, and the universities of Ontario: 1945-1980. University of Toronto Press.

Acker, S., \& Webber, M. (2016). Discipline and publish: The tenure review process in Ontario universities. In L. Shultz \& M. Viczko (Eds.), Assembling and governing the higher education institution (pp. 233-255). Palgrave Macmillan UK.

American Association of University Professors. (1915). Declaration of principles. http://www.aaup-ui.org/ Documents/Principles/Gen Dec Princ.pdf

American Association of University Professors. (1940). 1940 statement of principles on academic freedom and tenure. https://www.aaup.org/report/1940-statement-principles-academic-freedom-and-tenure

Banks, K. (1995). Weakening the tenure system: The misuse and abuse of sessional appointments. CAUT Bulletin, 42(5), 3.

Birdsell Bauer, L. (2017). Professors-in-training or precarious workers? Identity, coalition building, and social movement unionism in the 2015 University of Toronto graduate employee strike. Labor Studies Journal, 42(4), 273-294. https://doi. org/10.1177/0160449X17731877

Brownlee, J. (2015). Academia, Inc.: How corporatization is transforming Canadian universities. Fernwood.

Cameron, D. M. (1996). Academic freedom and the Canadian university. Association of Universities and Colleges of Canada.
Cameron, J. (2014). Giving and taking offense: Civility, respect, and academic freedom. In J. L. Turk (Ed.), Academic freedom in conflict (pp. 293-304). Lorimer.

Canadian Association of University Teachers. (1959). Report of the investigation by the Committee of the Canadian Association of University Teachers into the dismissal of Professor H.S. Crowe by United College, Winnipeg, Manitoba. CAUT Bulletin, 7(3), 3-91.

David, J. (2020, July 2). Tracking 'cancel culture' in higher education. National Association of Scholars. https://www.nas.org/blogs/article/tracking-cancel-culture-in-higher-education

Dea, S. (2018, October 9). A brief history of academic freedom. University Affairs. https://www.universityaffairs.ca/opinion/dispatches-academic-freedom/a-brief-history-of-academic-freedom/

Farr, M. (2018, August 28). Arbitration decision on student evaluations of teaching applauded by faculty. University Affairs. https://www. universityaffairs. ca/news/news-article/arbitration-decision-on-student-evaluations-of-teaching-applauded-by-facultyl

Field, C. C., \& Jones, G. A. (2016). A survey of sessional faculty in Ontario publicly-funded universities. Report to the Ontario Ministry of Advanced Education and Skills Development. Ontario Institute for Studies in Education. https://www.oise.utoronto.ca/hec/UserFiles/File/Sessional Faculty - OHCRIF Final Report - July 2016.pdf

Frontczak, D. (2020). Adjuncts and the chimera of academic freedom. Journal of Collective Bargaining in the Academy, 11, 1-11. https://thekeep.eiu.edu/jcbal vol11/iss $1 / 8$

Hanke, B. (2017). This is contract faculty time. Canadian Journal of Communication, 42, 49-66. https://doi. org/10.22230/cjc.2017v42n1a3100

Horn, M. (1975). The history of academic freedom in Canada: A comment. CAUT Bulletin, 24(3), 15-16.

Horn, M. (1999). Academic freedom in Canada: A history. University of Toronto Press.

Hughes, J., \& Bell, D. (2015). Bargaining for contract 
academic staff at English Canadian universities. Working USA: The Journal of Labor \& Society, 18(3), 377-394. http://dx.doi.org.proxy.library. brocku.ca/10.1111/wusa.12187

Hussein, E., \& and MacDermid, R. (2006). CAUT Ad Hoc Investigatory Committee report into the termination of Dr. Laurent Leduc's participation in the continuing education division program on corporate social responsibility at the University of St. Michael's College, the University of Toronto. Canadian Association of University Teachers. https://www.caut.cal docs/default-source/af-ad-hoc-investigatory-committees/report-on-the-discontinuance-of-dr-laurentleduc-at-the-university-of-st-michael\%27s-collegeuniversity-of-toronto-\%282006\%29.pdf?sfvrsn=4

Ibbott, P., Lozanski, K., \& Broad, G. (2014, February 26). CAUT's proposed censure of King's College: The view of King's faculty. University Affairs. https:/l www.universityaffairs.ca/opinion/in-my-opinion/ cauts-proposed-censure-of-kings-college-the-viewof-king-facultyl

Katz, A., \& Haxell, J. (2013). Report of the CAUT ad hoc investigatory committee on King's University College and professor Ken Luckhardt. Canadian Association of University Teachers. https://www. caut.ca/docs/default-source/reports/report-of-kingsluckhardt-inquiry--final.pdf?sfvrsn=6

MacKinnon, P. (2014). University leadership and public policy in the twenty-first century: A president's perspective. University of Toronto Press.

MacKinnon, P. (2018). University commons divided: Exploring debate and dissent on campus. University of Toronto Press.

Muzzin, L. (2009). Equity, ethics, academic freedom and the employment of contingent faculty. Academic Matters, May, 19-22. https://academicmatters.cal equity-ethics-academic-freedom-and-the-employment-of-contingent-academics/

Neem, J. (2019, April 16). The subtle erosion of academic freedom. Inside Higher Ed. https://www.insidehighered.com/views/2019/04/16/three-subtle-forces-weakening-academic-freedom-opinion

Polster, C. (2015). Rethinking and remaking academic freedom. In C. Polster \& J. Newson (Eds.), A penny for your thoughts: How corporatization devalues teaching, research, and public service in Canada's universities (pp. 303-312). Canadian Centre for Policy Alternatives.

Rajagopal, I. (2002). Hidden academics: Contract faculty in Canadian universities. University of Toronto Press.

Rogers, S. E., Eaton, A. E., \& Voos, P. B. (2013). Effects of unionization on graduate student employees: Faculty-student relations, academic freedom, and pay. Industrial \& Labor Relations Review, 66(2), 487510. https://doi.org/10.1177/001979391306600208

Ross, S., Savage, L., \& Watson, J. (2020). Interrogating the relationship between bargaining structures and bargaining outcomes for contract academic faculty in Ontario. Labour/Le Travail, 86(2), 9-43.

Sachs, J. (2018, April 27). There is no campus free speech crisis: A close look at the evidence. Niskanen Centre. https://www.niskanencenter.org/ there-is-no-campus-free-speech-crisis-a-close-lookat-the-evidencel

Savage, D. C., \& Holmes, C. (1975). The CAUT, the Crowe case, and the development of the idea of academic freedom in Canada. CAUT Bulletin, 24(3), 22-27.

Savage, D. C., \& Finn, P. A. (2017). The road to the 1997 UNESCO Statement on Academic Freedom. Canadian Association of University Teachers. https:/l www.caut.ca/sites/default/files/unesco en insidepages final2017-09-11.pdf

Smallman, V. (2006). Academic labor: The Canadian context. Cinema Journal, 45(4), 108-112. https://doi. org/10.1353/cj.2006.0047

Sylvester, D. (2014, March 3). Resolution of CAUT issue re. Ken Luckhardt. Open letter to the King's Community. https://www.kings.uwo.ca/kings/assets/ File/communications/news/Sylvester-CAUT-LETTER-02-28-2014.pdf

Tudiver, N. (1999). Universities for sale: Resisting corporate control over Canadian higher education. James Lorimer and Company. 
Turk, J. L. (Ed.). (2014). Academic freedom in conflict: The struggle over free speech rights in the university. James Lorimer and Company.

Turk, J. L. (2017). The landscape of the contemporary university. Canadian Journal of Communication, 42(1), 3-12. https://doi.org/10.22230/ cjc. $2017 \mathrm{v} 42 \mathrm{n} 1 \mathrm{a} 3202$

Universities Canada. (2011, October 25). Statement on academic freedom. http://www.univcan.cal media-room/media-releases/statement-on-academic-freedom/

Woodhouse, H. (2009). Selling out: Academic freedom and the corporate market. McGill-Queen's University Press.

\section{Contact Information}

Larry Savage

Isavage@brocku.ca

\section{Notes}

1 Town and gown refers to the dynamic between the two, often distinct, communities of a university town. The "town" refers to the non-academic population and "gown" to the academically-focused university campus. 